\title{
Analisis Kualitas Pelayanan pada Rumah Makan Panca Rasa Puruk Cahu
}

\author{
Rinto Alexandro ${ }^{1}$, Fendy Hariatama², Ela Norliana ${ }^{3}$ \\ 1,2,3Universitas Palangka Raya, Palangka Raya - Indonesia
}

\section{A R T I C L E I N F O}

Article history:

Received October, 242021

Received in revised form

November, 142021

Accepted November, 20

2021

Available online December,

252021

\section{Kata Kunci:}

Kualitas pelayanan,

rumah makan.

Keywords:

Quality of service,

restaurant

\begin{abstract}
A B S T R A K
Rumah makan panca rasa puruk cahu merupakan salah satu perusahaan yang ada di Murung Raya Provinsi Kalimantan Tengah, dimana usahanya bergerak dalam menyediakan produk (barang dan jasa). Dalam memberikan pelayanan kepada masyarakat Rumah Makan Panca Rasa dituntut untuk melakukan sesuatu yang terbaik dan memberikan kepuasan kepada pelanggan dalam pelayananya. Penelitian ini bertujuan untuk mengetahui kualitas pelayanan tentang kepuasan konsumen pada rumah makan panca rasa puruk cahu. Pendekatan penelitian yang digunakan adalah deskriftif kualitiatif dengan tekhnik pengumpulan data melalui: obeservasi, wawancara dan dokumentasi. Tekhnik analisis data: reduksi data penyajian data dan penarikan kesimpulan, dengan responden adalah konsumen pada Rumah Makan Panca Rasa, konsumen yang telah ditetapkan sebanyak 8 orang. Dari hasil analisis penelitian dapat ditarik kesimpulan bahwa, kualitas pelayanan ditunjukan dari aspek tangible, realibility, responsiveness, assumrance, dan emphaty pada rumah makan panca rasa puruk cahu adalah sebagai berikut aspke tangible (berwujud) memberikan fasilitas yang lengkap, penataan barang-barang dan penampilan karyawan yang bersih dan rapi. Pada aspek reability, menggunakan system manual dalam melakukan transaksi pembayaran jam operasional yang selalu tepat dan memberikan pelayanan yang sopan dan santun. Aspek resposivenes, selalu merespon/menanggapi keluhan dan komplain dari konsumen, tetapi konsumen harus terlebih dahulu mencari karyawan untuk mendapatkan
\end{abstract} pelayanan. Aspek ansurancce, memberikan jaminan keamanan, kenyamanan, dan jaminan terhadap produk yang dibeli konsumen serta karyawan memiliki kecakapan dan pengetahuan tentang produk yang dijual. Aspek emphaty, pegawai selalu berkomunikasi kepada konsumen.

\section{A B S T R A C T}

The Panca Rasa Puruk Cahu Restaurant is one of the companies in Murung Raya Central Kalimantan Province, where its business is engaged in providing products (goods and services). In providing services to the community, Panca Rasa Restaurant is required to do the best and provide satisfaction to customers in their services. This study aims to determine the quality of service about customer satisfaction at the Panca Rasa Puruk Cahu restaurant. The research approach used is descriptive qualitative with data collection techniques through: observation, interviews and documentation. Data analysis techniques: data reduction data presentation and drawing conclusions, with the respondents are consumers at the Panca Rasa Restaurant, consumers who have been set as many as 8 people. From the results of the research analysis, it can be concluded that the quality of service is shown from the aspects of tangible, realibility, responsiveness, assurance, and empathy at the Panca Rasa Puruk Cahu restaurant as follows: Tangible aspects provide complete facilities, arrangement of goods and appearance. Clean and tidy employees. In the aspect of reliability, using a manual system in making payment transactions for operating hours that are always correct and provide polite and courteous service. Responsiveness aspect, always responds / responds to complaints and complaints from consumers, but consumers must first find employees to get service. Aspects of assurance, providing security, comfort, and guarantees for products purchased by consumers and employees having skills and knowledge about the products being sold. Aspects of empathy, employees always communicate to consumers.

\footnotetext{
* Corresponding author.

E-mail : rintoalexandro@fkip.upr.ac.id (Rinto Alexandro)
} 


\section{Pendahuluan}

Dalam era globalisasi seperti sekarang ini, manajemen suatu perusahaan sangat dituntut kedinamisanya, kemampuan dan keberaniannya dalam memunculkan inovasi dan ide baru demi eksistensi perusahaan agar tidak jauh tertinggal hingga akhirnya dikalahkan oleh pesaingnya. Pesaing ini tidak dapat dihindari karena pasti akan terjadi disemua jenis bidang usaha. Menurut (Hasibuan, 2008), manajemen hanya merupakan alat untuk mencapai tujuan yang diinginkan. Manajemen yang baik akan memudahkan terwujudnya tujuan perusahaan, karyawan, dan masyarakat. Dalam suatu perusahaan atau badan usaha harus dapat menggunakan dan menggelola sumberdaya yang tersedia, dalam hal ini pula perusahaan harus memperhatikan konsumen yang ada. Memperhatikan dalam usaha pemasaran dikenal istilah bahwa konsumen (pelanggan) adalah "raja".

Dalam strategi pemasaran yang menjadi pusat perhatian awal adalah konsumen itu sendiri, dalam hal ini, konsumen harus dipuaskan dalam hal kualitas pelayanan, karena jika tidak puas maka konsumen tidak tertarik lagi pada perusahaan tersebut, oleh karena itu pemimpin usaha harus berusaha melakukan pengukuran untuk mengetahui tingkat kepuasan pelanggan dan mengetahui atribut apa dari suatu produknya (barang atau jasa) yang dapat membuat pelanggan merasa puas.

Rumah makan panca rasa yang berada di kota puruk cahu provinsi kalimantan tengah merupakan rumah makan yang menyediakan beraneka menu makanan dan miniman, baik dari tradisional hingga modern. Ditengah persaingan yang begitu ketat, kualitas pelayanan tentunya menjadi salah satu fokus demi manjaga keberlangsungan rumah makan panca rasa. Menurut (Dharmayasa dan Tripalupi, 2014) kualitas pelayanan pada dasarnya merupakan suatu kegiatan pelayanan yang diberikan kepada pelanggan sesuai dengan prinsip lebih mudah, lebih baik, cepat, tepat, akurat, ramah, dan sesuai dengan keinginan pelanggan. Tentu saja rumah makan yang dapat menerapkan prinsip-prinsip tersebut dalam memberikan pelayanan kepada konsumennya akan memiliki nilai lebih dimata konsumen.

Pendapat lainnya (Wirapradnyana, 2013) menyampaikan pertimbangan yang dapat dijadikan pedoman dalam menentukan keputusan konsumen menggunakan jasa adalah kualitas pelayanan. Inilah yang kemudian menjadi fokus penulis dalam menjadikan rumah makan panca rasa sebagai objek penelitian guna mengetahui kualitas pelayanan yang diberikan kepada para konsumennya agar konsumen rumah makan tersebut tidak berpaling dan pergi mencari rumah makan yang lain. Menurut (Kotler, 2006: 202) mempertahankan dan membesarkan pelanggan adalah hal yang utama. Perusahaan telah banyak mengeluarkan dana untuk mendapatkan pelanggan yang sekarang ada, dan pesaing selalu merebut mereka. Jadi pada prinsipnya rumah makan panca rasa harus memantau tingkat kepuasan pelanggan terhadap produk yang sudah ditawarkan kepada pihak konsumen. Setiap langkah perusahaan untuk menggembangkan diri dapat dengan mudah ditiru oleh perusahaan lain, sebaliknya sumber daya manusia merupakan sumber keunggulan yang potensial karena kompetensi yang dimilikinya berupa intelektualitas, keterampilan, karakter personal, tidak dapat ditiru oleh perusahaan lain.

Menurut (Gerson 2004:42) mutu pelayanan adalah sasaran untuk mencapai kepuasan dan ikatan, tujuan bisnis bukan hanya laba, tetapi bagaimana cara memberikan pelayanan yang prima yang dapat memberikan kepuasan pelanggan. Dengan demikian mereka yang kecewa dengan pelayanan tidak hanya meninggalkan perusahaan, tetapi juga akan menceritakan keburukan yang diterima pada orang lain. Citra buruk akan melekat dalam perusahaan tersebut.

Bilamana hal ini sampai terjadi tentu saja akan memberikan dampak terhadap calon konsumen yang bisa saja akan menjatuhkan pilihan kepada rumah makan lain. Efek berikutnya akan terjadi permintaan negative dalam jangka panjang. Dan sekali lagi itu berarti kerugian bagi rumah makan panca rasa. Lebih parah lagi, kerugian ini berlanjut ketika perusahaan berupaya mendapatkan pelanggan baru. Menurut penelitian, diperlukan biaya lima kali lipat untuk mendapatkan seorang kosumen baru, dibandingkan mempertahankan seorang yang telah menjadi pelanggan. Belum lagi berapa banyak energi yang harus dikerahkan untuk hal tersebut (Parasuranman dalam Nasution, 2004:60) tentu akan lebih hemat bila perusahaan menginvestasikan sejumlah uang untuk meningkatkan sistem kualitas pelayanan kepada konsumen dibanding menelan kerugian yang sudah pasti tidak sedikit. Upaya perbaikan sistem pelayanan, termasuk menangani keluhan konsumen, diyakini jauh lebih efektif bagi kelangsungan bisnis. Upaya perbaikan ini akan menjadikan pelanggan makin setia kepada perusahaan dalam hal ini rumah makan panca rasa. Pelanggan yang setia ibarat darah bagi perusahaan. Tanpa itu perusahaan akan mati, sebagaimana manusia tanpa darah.

Berdasarkan hal tersebut di atas, maka sangat diperlukan adanya upaya peningkatan kesadaran akan pentingnya membangun sistem manajemen pelayanan dan memberikan kualitas pelayanan dalam aktifitas operasional rumah makan panca rasa. Fokus pada pelayanan kepada konsumen dipersyaratkan sebagai sesuatu yang harus dipenuhi untuk meningkatkan kepuasan pelanggan. Sehingga berdasarkan 
beberapa hal tersebut di atas penulis ingin melakukan penelitian dengan mengangkat sebuah judul Analisis Kualitas Pelayanan Pada Rumah Makan Panca Rasa Puruk Cahu.

\section{Metode}

Pendekatan dan penelitian yang digunakan ini adalah pendekatan kualitatif. Menurut (Sugiyono, 2007), metode penelitian kualitatif merupakan suatu penelitian yang digunakan untuk meneliti pada objek yang alamiah dimana peneliti adalah sebagai instrumen kunci, teknik pengumpulan data dilakukan secara gabungan, analisis data bersifat induktif, dan hasil penelitian kualitatif lebih menekankan makna daripada generalisasi. Selanjutnya menurut (Moleong, 2007:27), "Penelitian kualitatif adalah tampilan yang berupa kata-kata lisan atau tertulis yang dicermati oleh peneliti, dan benda-benda yang diamati sampai detailnya agar dapat ditangkap makna yang tersirat dalam dokumen atau bendanya".

Untuk memperoleh data yang akurat dalam penelitian ini, penulis menggunakan beberapa teknik pengumpulan data, yaitu observasi/pengamatan, wawancara, dan dokumentasi. Menurut (Widoyoko, 2014:46) observasi merupakan "pengamatan dan pencatatan secara sistematis terhadap unsur-unsur yang nampak dalam suatu gejala dalam objek penelitian". Dokumentasi dalam penelitian ini adalah mengumpulkan data yang peroleh dari rumah makan panca rasa. Menurut (Afifuddin, 2009:131) wawancara adalah metode pengambilan data dengan cara menanyakan sesuatu kepada seseorang yang menjadi informan atau responden.

Penelitian ini dilakukan pada Rumah Makan Panca Rasa Puruk Cahu Provinsi Kalimantan Tengah. Sumber data dibagi menjadi dua yaitu data primer dan data sekunder. 1. Data primer adalah data yang diperoleh peneliti secara langsung (dari tangan pertama). 2. Data sekunder atau data pendukung dalam penelitian ini bersumber dari beberapa literature atau dokumen serta gambaran umum tentang kualitas pelayanan dan kepuasan konsumen pada Rumah Makan Panca Rasa Puruk Cahu. Adpun informan atau objek peneitian yaitu pemilik rumah makan, karyawan rumah makan, dan konsumen.

\section{Hasil dan pembahasan \\ a. Hasil Penelitian}

Untuk mengetahui kualitas layanan dan kepuasan konsumen Rumah Makan Panca Rasa Saat ini, peneliti memilih menggunakan 5 dimensi kualitas pelayanan jasa yang dikemukakan oleh parasuraman dalam Nasution (2004: 60) adalah sebagai berikut: yaitu Tangibel (wujud), Reability (kehandalan), Responsiviness (ketanggapan), Assurance (jaminan), dan Empaty (empaty). Dibawah ini akan dipaparkan data wawanacara dengan pihak Rumah Makan Panca Rasa mengenai kepuasan kualitas pelayanan yang diberikan sebagai berikut:

Wawancara peneliti dengan bapak Muksin selaku pemilik rumah makan panca rasa

\section{1) Reability (kehandalan)}

Melaksanakan pelayanan yang dijanjikan secara meyakinkan dan akurat, variabel-variabelnya: Ketepatan waktu buka, sopan santun karyawan. Seperti hasil wawancara peneliti dengan bapak Muksin selaku pemilik rumah makan panca rasa, dan saudari Midayanti dan juga saudari Husna selaku konsumen dari Rumah Makan Panca Rasa sebagai berikut:

a) Bagaimana pelayanan yang diberikan oleh karyawan rumah makan panca rasa, apakah memuaskan? Jawaban: Ya, semestinya begitu karena kami melakukan pelayanyang maksimal, sesuai dengan pelayanan standar-standar yang ada dirumah makan Panca Rasa, kami juga juga menerima kritik dan saran yang disampaikan konsumen baik dari menu masakan atau pelayanan diberikan kepada kami sehingga penilaian itu memberikan keputusan akhir sehingga kita bisa melihat sejauh mana pelayanan yang kami berikan (wawancara pada hari rabu, 9 Oktober 2019 pemilik).

b) Apakah pelayanan yang diberikan oleh karyawan rumah makan panca rasa kepada pembeli yang datang belanja, sopan dan ramah?

Jawaban: Yaa, pasti lah seperti itu, ada standarisasi jadi orang siklus datang kesini itu sudah dilayani dari setiap mereka masuk sampai mereka keluar (wawancara pada hari rabu, 9 Oktober 2019 pemilik).

c) Apakah jam buka rumah makan panca rasa tepat waktunya?

Jawaban: Kadang tepat sekali kadang lewat 15 menit sampai 20 menit, misalnya harinya hujan dari malam itu sedikit mengganggu misalnya stok barang habis, itu pengantarannya pada pagi hari sekitaran jam 5 pagi, atau ada sebagian yang kepasar, dengan adanya hujan membuat perjalanan sedikit terganggu sehingga mengakibatkan ada sedikit kerterlambatan jam bukanya, tapi itu jarang terjadi keseringan tepat waktu (wawancara pada hari rabu, 9 Oktober 2019 pemilik). 


\section{2) Responsiveness (daya tanggap)}

Kesediaan membantu pelanggan dan memberikan jasa dengan cepat, variabel-variabelnya:

a) Kesiapan menanggapi permintaan pelanggan,

b) Layanan yang cepat kepada pelanggan dalam mengalami keluhan. Seperti hasil wawancara peneliti dengan bapak Muksin selaku pemilik rumah makan panca rasa, dan saudari midayanti dan juga saudari husnaselaku konsumen dari Rumah Makan Panca Rasa sebagai berikut:

1) Apakah karyawan cepat merespon terhadap keluhan konsumen? Jawaban: Yaa, yang pertama begitu ada keluhan langsung kita handle dengan cara face to face, yang bisa kita handle atas komplain konsumen kasus ini pernah kami alami, karena begini tidak mungkin suatu jasa yang tidak pernah mendapatkan suatu keluhan, tapi bagaimana suatu keluhan itu kita selesaikan dengan baik (wawancara pada hari rabu, 9 Oktober 2019 pemilik).

2) Apakah karyawam rumah makan panca rasa selalu siap melayani konsumen? Jawaban: Iyaa, pasti setiap hari kami selalu siap standby melayani konsumen, terus kalau ada konsumen yang pesan atau tambahan dalam pemesanan menu kami selalu siap ini kenapa sebab kami buka lebar tidak ada pembatas dari tempat kasir atau tempat karyawan menunggu agar kami bisa selalu liat kalau ada konsumen yang memberi kode minta pelayanan (wawancara pada hari rabu, 9 Oktober 2019 pemilik).

3) Respon seperti apa yang dilakukan karyawan rumah makan panca rasa dalam menghadapi komplain customer?

Jawaban: Misalnya ada konsumen yang salah tulis dia pesan satu tapi ditulisnya dua, atau misalnya salah yang dia pesan sama yang kami kasih itu mereka dengan menanggapinya (wawancara pada hari rabu, 9 Oktober 2019 pemilik)

\section{3) Assurance (jaminan)}

Pengetahuan dan kesopanan karyawan dan kemampuan mereka menyampaikan kepercayaan dan keyakinan, variabel-variabel 1) pengetahuan dan kecakapan karyawan 1) komunikasi yang efektif kepada pelanggan. Seperti hasil wawancara peneliti dengan bapak Muksin selaku pemilik rumah makan panca rasa, dan saudari midayanti dan juga saudari husna selaku konsumen dari Rumah Makan Panca Rasa sebagai berikut:

a) Apakah merasa aman dan nyaman ketika dilayani oleh karyawan?

Jawaban: Aman dalam arti apa dulu, aman karena ada macamnya yang pertama aman internal dan aman secara konsepnya. Misalnya ada konsumen yang makan tiba ketinggalan kaya hp nya, itu kami simpan sampai dia kembali la gitu juga yang lainnya misalnya dokumenya kan orang kantoran sering bangat kesini, memang disini belum menyediakan CCTV, tapi kami pastikan aman jika memang barang yang bersangkutan memang disini kalau sudah keluar dari sini sudah bukan tanggung jawab kami mba, kami berusaha memberikan kenyaman dan keamanan baik dari segi kebersihan tapi kami juga minta konsumen juga menciptakan rasa aman kepada dirinya dan juga barang-barangnya sendiri (wawancara pada hari rabu, 9 Oktober 2019 pemilik ).

b) Apakah semua pegawai rumah makan panca rasa, mengetahui semua tentang masakan yang di masak? Jawaban: Iyaa, rata-rata mereka bisa menjelaskan misalnya kalau ada konsumen yang Tanya, ini masakan ini kaya gimana mereka bisa jelasin dari bahannya, campurannya, hingga dimasak sehingga konsumen bisa membayangkan rasanya dari apa yang sudah dijelaskan oleh karyawan, lebih khususnya mereka mengetaui itu penting menurut saya karena bisa memberi gambaran kepada konsumen, seperti itu mba (wawancara pada hari rabu, 9 Oktober 2019 pemilik).

\section{4) Emphaty (empati)}

Kesedian memberikan perhatian khusus kepada pelanggan, variabel-variabel:

a) Perhatian secara individu kepada pelanggan.

b) Memperhatikan kebutuhan dan keperluan pelanggan.

1) Bagaimana sikap karyawan rumah makan panca rasa ketika melihat konsumen yang datang membeli?

Jawaban: Saat pelanggan datang harus sudah disapa dengan senyuman, dan langsung bertanya apa yang mau dipesan searaya menyodorkan daftar menu, serta memberikan kertas dan polpen untuk mencatat menu apa saja yang dipesan,kadang karyawan tinggal sebentar sementara pelanggan memilih menu yang ada dipesan selanjutnya karyawan kami melihat kembali apa yang ditulis dan jika belum jelas karyawan akan bertanya, tapi jika sudah jelas karyawan langsung mebawa tulisan itu ketempat penyajian agar dimasak menu yang dipesan dan kemudian ditaruh dikasir untuk 
menotalkan jumlah harga menu yang dipesan konsumen tersebut mba (wawancara pada hari rabu, 9 Oktober 2019 pemilik)

2) Bentuk komunikasi danperhatian seperti apa yang diberikan kepada konsumen? Jawaban: Seperti yang saya bilang sebelumnya tadi, misalkan konsumen datang kami selalu menawarkan menu, dan jika belumjelas kami berusaha menjelaskan sampai konsumen paham dengan apa yang tidak dia pahami dari menu makanan, campuran makan dan minuman yang akan dia pesan. Misalkan dia kurang menyukainya kami akan menawarkan menu lain, tapi kebanyakan orang datang langsung pesan kerena mereka sudah terbiasa makan disini, kebanyakan kan pelanggannya orang yang tinggal dipuruk cahu semua (wawancara pada hari rabu, 9 Oktober 2019 pemilik).

\section{5) Tangible (Berwujud)}

Penampilan fasilitas fisik, pelengkap karyawan, dan bahan komunikasi, variabel-variabal:

a) Kebersihan dan kerapian.

b) Karyawan memiliki penampilan rapi. Seperti hasil wawancara peneliti dengan bapak Muksin selaku pemilik rumah makan panca rasa, dan saudari midayanti dan juga saudari husna selaku konsumen dari Rumah Makan Panca Rasa sebagai berikut:

1) Bagaimana ruamah makan panca rasa puruk cahu dalam menata barang-barangnya? Jawaban: Setiap tiga bulan kami ada namanya bedah counter, dimana kami menata ulang susunan meja kursi yang ada diruangan, agar pengunjung tidak merasa bosan dengan suasana yang itu itu saja. Kami semuanya sama berkreasi tetapi masih dalam arahan dan bimbingan saya. (Wawancara pada hari rabu, 9 Oktober 2019 pemilik).

2) Fasilitas apa saja yang diberikan Rumah makan panca rasa puruk cahu? Jawaban: Disini kami menyediakan toilet, yang cukup baik, bersih, wangi, tempat mencuci tangan bersih dan harum (wawancara pada hari rabu, 9 Oktober 2019 pemilik).

3) Apakah karyawan yang melayani konsumen kelihatan rapi dan bersih?

Jawaban: Iya rapi bersih sesuai dengan standar yang di berikan oleh rumah makan panca rasa tersebut (wawancara pada hari rabu, 9 Oktober 2019 pemilik).

Wawancara Konsumen

Tangible (bukti fisik)

1) Bagaimana penataan dan pengaturan barang-barang, apakah rapi? Tanggapan husna sebagai berikut: Rapi mba dan bersih juga (wawancara pada hari rabu, 9 Oktober 2019 pelanggan)

2) Bagaimana fasilitas yang diberikan rumah makan panca rasa? Tanggapan husna sebagai berikut: Bagus mba, lumayan memadai, dari segi fasilitas, untuk pelayanan saya juga merasa puas (wawancara pada hari rabu, 9 Oktober 2019 pelanggan)

3) Apakah karyawan yang melayani konsumen kelihatan rapi dan bersih? Tanggapan husna sebagai berikut: Iyaa mba kelihatan bersih dan rapi (wawancara pada hari rabu, 9 Oktober 2019 pelanggan)

Reability (kehandalan)

1) Bagaimana pelayanan yang diberikan oleh karyawan rumah makan panca rasa, apakah memuaskan? Tanggapan husna sebagai berikut: Iyaa lumayan bagus dan lumayan memuaskan juga mba (wawancara pada hari rabu, 9 Oktober 2019 pelanggan)

2) Apakah pelayanan yang diberikan oleh karyawan rumah makan panca rasa kepada pembeli yang datang belanja, sopan dan ramah? Tanggapan husna sebagai berikut: Kalo rame ya antri mba, tapi kalau sepi misalnya dipagi hari itu tidak antri kecuali kalau pas jam makan siang sampai sore mba (wawancara pada hari rabu, 9 Oktober 2019 pelanggan)

3) Apakah jam buka rumah makan panca rasa tepat waktunya? Tanggapan husna sebagai berikut: Kadang lambat kadang tepat waktu bangat mba (wawancara pada hari rabu, 9 Oktober 2019 pelanggan)

Responsiveness (daya tanggap)

1) Apakah karyawan cepat merespon terhadap keluhan konsumen? Tanggapan indra sebagai berikut: Kalau saya pernah komplain soalnya makanannya asin dengan baik mereka tanggapi bahkan menawarkan untuk menggantinya, kalau basi sih gak ya mba soalnya ini fresh semua dimasak saat dipesan gitu (wawancara pada hari rabu, 9 Oktober 2019 pelanggan)

2) Apakah karyawan rumah makan panca rasa selalu siap melayani konsumen? Tanggapan indra sebagai berikut: Biasanya selalu langsung dengan cepat mereka menanggapi (wawancara pada hari rabu, 9 Oktober 2019 pelanggan) 
3) Respon seperti apa yang dilakukan karyawan rumah makan panca rasa dalam menghadapi komplain customer? Tanggapan indra sebagai berikut: Iya tadi selalu cepat menanggapi (wawancara pada hari rabu, 9 Oktober 2019 pelanggan)

Assurance (jaminan)

1) Apakah merasa aman dan nyaman ketika dilayani oleh karyawan? Tanggapan indra sebagai berikut: Aman aja nyaman aja mba tidak aneh-aneh (wawancara pada hari rabu, 9 Oktober 2019 pelanggan)

2) Apakah semua pegawai rumah makan panca rasa, mengetahui semua tentang masakan yang di masak? Tanggapan indra sebagai berikut: Iyaa dulu saya petama kesini belum tau kaya gimana masakannya mereka jelaskan sama saya, saya kan orang banjar mba jadi lebih sering kaya masak merah atau makanan khas banjar lah, jadi agak asing sama masakan kaya oseng-osengan gituu jadi mereka bisa menjelaskan sama saya (wawancara pada hari rabu, 9 Oktober 2019 pelanggan)

Emphaty (empati)

1) Bagaimana sikap karyawan rumah makan panca rasa ketika melihat konsumen yang datang membeli? Taggapan rahmat sebagai berikut: Mereka senyum mba langsung ngasih menu makanan sambil ngomong silahkan (wawancara pada hari rabu, 9 Oktober 2019 pelanggan)

2) Apakah konsumen diajak berkomunikasi? Taggapan rahmat sebagai berikut: Iya kaya misalnya silahkan, atau kalau kita nanya mereka jawab dan kalau kita bawa komunikasi mereka akan layani kalau masalah komunikasi sih tergantung kita ya, mereka cuma komunikasi seperlu mungkin takut ganggu pelanggan (wawancara pada hari rabu, 9 Oktober 2019 pelanggan.

Wawancara Karyawan Rumah Makan Panca Rasa

a. Reability (kehandalan)

1) Bagaimana cara anda melayani konsumen, agar konsumen puas terhadap pelayanan yang ada berikan? Dan juga dikatakan oleh saudari Midayanti sebagai karyawan: Saat petama pelanggan datang kami sudah menyambut dengan ramah kami pun selalu siap seandainnya pelanggan membutuhkan jasa kami, karena untuk menciptakan kepuasan bukan hanya dari menu masakan yang kami suguhkan tetapi juga tingkah laku dan sopan santun, kebersihan, kerapian kami juga dinilai dalam melayani (wawancara pada hari rabu, 9 Oktober 2019 karyawan)

2) Bagaimana pelayanan yang ada berikan kepada konsumen, apakah harus sopan dan santun? Ya harus mba, seperti yang saya bilang sebelumnya, kami harus sopan santun kepada tamu, karena kata bapak muksin sendiri untuk mendapatkan citra yang baik harus melakukan yang terbaik baik (wawancara pada hari rabu, 9 Oktober 2019 karyawan)

3) Bagaimana jam operasional rumah makan panca rasa? Untuk jam operasional sendiri kami kadang tepat waktu kadang lewat 15 menit sampai 20 menit dari jam 08: 00 WIB tapi sering tepat sihh (wawancara pada hari rabu, 9 Oktober 2019 karyawan)

b. Responsiveness (daya tanggap)

1) Bagaimana cara kalian merespon keluhan/komplain dari customer? Kami akan teliti kalau kesalahan itu dari kami, kami akan menyikapi, kami akan menggantinya dengan yang baru (wawancara pada hari rabu, 9 Oktober 2019 karyawan)

2) Apakah anda dituntut selalu siapa/standby dalam melayani konsumen? Pasti mba karena kami tidak mau citra kami rusak dalam hal pelayanan (wawancara pada hari rabu, 9 Oktober 2019 karyawan)

c. Assurance (jaminan)

1) Bagaiman cara anda melayani konsumen agar mereka merasa aman dan nyaman? Yang pastinya kami tidak berbuat yang aneh-aneh sesuai prosedur saja (wawancara pada hari rabu, 9 Oktober 2019 karyawan)

2) Apakah anda mengetahui tentang menu-menu yang dijual dirumah makan ini? Iyaa mba, itu modal kami saat ada pelanggan yang bertanya (wawancara pada hari rabu, 9 Oktober 2019 karyawan)

d. Emphaty (empati)

1) Bagaimana sikap kalian kepada konsumen yang datang membeli? Kami layani dengan sopan dan santun (wawancara pada hari rabu, 9 Oktober 2019 karyawan)

2) Bentuk komunikasi seperti apa yang anda berikan kepada konsumen? Misalnya, pelanggan datang kami sapa dan senyum seraya menyodorkan menu makanan kepada pelanggan (wawancara pada hari rabu, 9 Oktober 2019 karyawan)

3) Bagaimana bentuk perhatian yang anda berikan kepada konsuemn yang datang membeli? Misalnya saat ada pelanggan yang datang dan bingung memilih menu apa yang mereka pesan kami akan menyarankan menu yang paling disukai disini misalnya capcay dan tongseng daging (wawancara pada hari rabu, 9 Oktober 2019 karyawan) 
e. Tangible (bukti fisik)

a. Bagaimana cara anda dalam penataan ruangan rumah makannya? Kami disini berkreasi tetapi dibawah bimbingan bapak juga (wawancara pada hari rabu, 9 Oktober 2019 karyawan)

b. Fasilitas apa saja yang ada di rumah makan panca rasa? Disini kami menyediakan Kamar mandi (wc), Kipas angin, Tv, Meja makan untuk pengunjung (10 meja dengan 4 kursi tiap mejanya), Kulkas untuk menyimpan minuman botol, Tempat mencuci tangan untuk pengunjung, Parkiran juga (wawancara pada hari rabu, 9 Oktober 2019 karyawan).

c. Untuk penampilan karyawan apakah ada standar khusus? Kalau hari-hari kami bebas rapi, tapi kalau ada acara resmi pesan catering sama kami kami punya seragam khusus juga (wawancara pada hari rabu, 9 Oktober 2019 karyawan).

Temuan Penelitian

Adapun temuan penelitian setelah diadakannya penelitian dirumah makan panca rasa, peneliti mendeskripsikan hasil analisis dan temuan penelitian sesuai dengan fokus penelitian peneliti yang berkaitan dengan Analisis kualitas pelayanan dan kepuasan konsumen pada rumah makan panca rasa puruk cahu. Temuan penelitian yang ditemukan adalah:

a. Dalam hal kualitas pelayanan menyangkut masalah Tangible (bukti fisik): suasana rumah makan yang nyaman ,dingin walaupun tak berAC, tempat cuci tangan, toilet dan karyawan yang ramah dan sopan dalam melayani konsumen. Dalam hal kualitas pelayanan menyangkut masalah Reability (kehandalan): ada masalah dibagian kasir ketika membayar, kerena kasir hanya melayani satu orang saja, dan pembeli yang lain harus mengantri untuk membayar.

b. Dalam hal kualitas pelayanan menyangkut masalah Responsiveness (daya tanggap): tidak ada masalah karena karyawan menunggu di depan pintumasuk dekat kasir jadi jika ada tamu yang datang karyawan langsung

c. Dalam hal kualitas pelayanan menyangkut masalah Assurance (jaminan): semua menu yang dijual memang tidak ada garansi seperti halnya barang elektronik tetapi jika setelah dipesan mendapat keluhan saat dimakan kami siap mengganti menu tersebut seandainya terjadi kesalahan dari pihak rumah makan tersebut.

d. Dalam hal kualitas pelayanan menyangkut masalah Emphaty (empati) Ada dua kata yaitu verbal dan non verbal senyum dan menyapa.

\section{b. Pembahasan}

Untuk mengetahui kualitas pelayanan tentang kepuasan konsumen rumah makan panca rasa ini, peneliti memilih menggunakan lima dimensi kualitas pelayanan dikemukakan oleh Parasuraman dalam (Nasution, 2004:60) memutuskan yaitu Tangibel (berwujud), Reability (kehandalan), Responsiveness (daya tanggap), Assurance (jaminan), dan Emphaty (empati). Hasil dan analisis kualitatif terhadap masingmasing dimensi kualitas pelayanan dapat diuraikan dengan penjelasan sebagai berikut:

\section{Dimensi Tangibel (berwujud)}

Pada penelitian ini, Tangibel mencakup hal-hal sebagai berikut: penampilan fisik, pelengkap karyawan dan bahan komunikasi. Dimensi Tangibel (berwujud) Ditentukan oleh indikator-indikator yaitu bagaimana rumah makan panca rasa dalam penataan barang-barangnya, fasilitas apa saja yang diberikan rumah makan panca rasa dan tampilan pegawainya serta apa saja yang diberikan oleh rumah makan panca rasa puruk cahu. Rangkaian analisis kualitatif pada indicator Dimensi Tangibel (berwujud) Dapat dijelaskan sebagai berikut: kualitas pelayanan pada konsumen rumah makan panca rasa oleh karyawan rumah makan panca rasa. Dimana pihak rumah makan panca rasa memberikan fasilitas yang memadai, penataan barangbarang dan penampilan karyawan yang bersih dan rapi.

\section{Dimensi Reability (kehandalan)}

Reability merupakan kemampuan untuk memberikan pelayanan yang dijanjikan secara meyakinkan dan akurat. Kualitas pelayanan untuk kepuasan konsumen yang dilakukan oleh rumah makan panca rasa. Dimensi Reability ditentukan oleh indikator-indikator kecermatan, standar pelayanan, ketepatan waktu buka dan sopan santun karyawan. Rumah makan panca rasa dalam melakukan transaksi pembayaran menggunakan sistem manual saja, selain kasirnya satu sistemnya juga manual ini yang menyebabkan antri pada saat melakukan pembayaran, dalam jam oprasional rumah makan panca rasa kadang lewat 15 menit 20 menit dari jam yang telah ditentukan. Rangkaian analisis kualitatif pada indikator Reability (kehandalan) Dapat dijelaskan sebagai berikut: dimana pihak rumah makan panca rasa menggunakan cara manual dalam transaksi tidak menggunakan computer, jam operasional yang tidak tepat bisa lewat beberapa menit dan karyawan memberikan pelayanan yang sopan dan santun. Sehingga konsumen merasakan antri karena terbatasnya jumlah kasir yang ada di rumah makan tersebut. 


\section{Dimensi Responsiveness (daya tanggap)}

Responsiveness merupakan kesedian dalam membantu pelanggan dan memberikan jasa cepat. Dimensi Responsiveness dalam penelitian ini ditentukan oleh indikator-indikator kesiapan untuk menanggapi permintaan pelanggan, tepat waktu dan merespon keluhan-keluhan pelanggan. Rumah makan panca rasa cepat dalam merespon keluhan dari konsumen karena rumah makan panca rasa menghadapi keluhan langsung face to face sehingga keluhan itu bisa dihandle. Rangkaian analisis kualitatif pada indikator Responsiveness (daya tanggap) dapat dijelaskan sebagai berikut: pihak rumah makan panca rasa selalu merespon atau menanggapi keluhan-keluhan pada komplain dari konsumen, memberikan pelayanan yang sopan dan santun. Dan karyawan selalu standby di dekat pintu masuk untuk melayani pelanggan yang datang.

\section{Dimensi Assurance (jaminan)}

Assurance merupakan kemampuan dalam memberikan jaminan, jaminan pengetahuan dan kesopanan karyawan, kemampuan mereka menyampaikan kepercayaan dan keyakinan dalam proses pelayanan pada konsumen rumah makan panca rasa, Dimensi Assurance ini ditentukan indikator-indikator, yaitu jaminan keamanan dan kenyamanan, pengetahuan dan kecakapan karyawan. Rumah makan panca rasa menjamin keamanan dan keyamanan misalkan ada barang yang tertinggal, mereka akan menyimpan sampai pemiliknya kembali, pihak rumah makan panca rasa sendiri akan mengganti makan yang mereka pesan jika ditemukan adanya kesalahan dari pihak rumah makan itu sendiri. Rangkaian analisis kualitatif pada indikator Assurance (jaminan) dapat dijelaskan sebagai berikut: dimana pihak rumah makan panca rasa, memberi jaminan keamanan dan kenyamanan yang pasti kepada para konsumen yang datang membeli selain itu karyawan juga memiliki kecakapan dan pengetahuan tentang menu makanan yang dijual.

\section{Dimensi Emphaty (empati)}

Emphaty yaitu kesedian memberikan perhatian khusus kepada masingmasing pelanggan. Dimensi Emphaty (empati) dilakukan oleh indikator-indikator:

1) perhatian secara individu kepada pelanggan.

2) memperhatikan kebutuhan dan keperluan pelanggan.

Sikap karyawan rumah mkan panca rasa saat melihat konsumen yaitu senyum dan menyapa, ada bahasa verbal danada bahasa non verbal bahasa non verbal seperti senyum, bahasa verbal dan ucapan mau pesan apa bapak/ibu dan mba. Selain itu komunikasi dan perhatian kepada para konsumen yang datang membeli, karyawan datang dan menghampiri dan menawarkan menu makanan kepada konsumen serta memberi polpen dan kertas untuk mencatat menu yang akan dipesan. Rangkaian analisis kualitatif pada dimensi emphaty dapat dijelaskan sebagai berikut: pegawai selalu berkomunikasi dan memberikan perhatian kepada konsumen, dan konsumen datang langsung dilayani karena tempat tunggu karyawan tepat disamping pintu masuk konsumen

Dengan diketahuinya proses pelayanan pada rumah makan panca rasa diharapkan dapat memberikan gambaran kepada pihak pengelola dalam meningkatkan kualitas pelayanan, yang tentunya akan berkaitan langsung dengan pemasaran dan keberlangsungan rumah makan seperti penelitian terdahulu yang pernah dilakukan (Hariatama, 2021) pelayanan dalam pemasaran yang merupakan salah satu kegiatan pokok yang dilakukan oleh perusahaan dalam upaya menjaga dan meningatkan kelangsungan hidup usahanya. Serta (Sartika, 2019) yang menyampaikan "Kualitas pelayanan ini dapat diartikan sebagai tingkat kepuasan tamu atau konsumen" yang tentu saja harus menjadi perhatian bagi rumah makan panca rasa.

\section{Simpulan dan saran \\ a. Simpulan}

Berdasarkan hasil penelitian dan pembahasan yang telah dikemukakan pada Bab sebelumnya, dapat ditarik kesimpulan yaitu: Kualitas pelayanan ditunjukan dari aspek tangible (berwujud), realibility (kehandalan), responsivness(respon/ketanggapan), assurance(jaminan), emphaty (empati) pada Rumah Makan Panca Rasa Puruk Cahu.adalah sebagai berikut:

1) Aspek realibity (kehandalan), menggunakan sistem manual dalam transaksi pembayaranya, jam operasioanl yang tidak tepat waktu dan memberikan pelayanan yang sopan dan santun.

2) Aspek tangible (berwujud) Dimana Pihak Rumah Makan memberikan fasilitas yang memadai, penataan barang-barang dan penampilan karyawan yang bersih dan rapi.

3) Aspek responsiveness (respon/ketanggapan), selalu menanggapi keluhan dan komplain dari konsumen. Tetapi konsumen harus terlebih dahulu mencari karyawan untuk mendapatkan pelayanan. 
4) Aspek assurance (Jaminan), memberikan jaminan keamanan, kenyamanan dan jaminan terhadap produk yang dibeli konsumen. Selain itu karyawan memiliki kecapakan dan pengetahuan tentang menu makan yang dijual.

5) Aspek emphaty (empati), pegawai selalu berkomunikasi kepada konsumem melayani konsumen bahkan saat pertama datang karena memang tempat karwayan menunggu di samping pintu masuk pelanggan.

Konsumen yang datang ke Rumah Makan Panca Rasa Puruk Cahu pada dasarnya karena, serta menu makanan yang dijual dan bervariasi. Konsumen juga menciptakan world of mounth. Dalam hal menciptakan citra merek, konsumen masih sering makan ditempat lain selain yang dijual dirumah makan panca rasa. Selain itu konsumen membeli makanan tidak hanya satu menu saja, tetapi juga menu lain.

\section{b. Saran}

Berdasarkan hasil penelitian ini dapat disampaikan beberapa saran sebagai berikut:

1) Bagi Rumah Makan Panca Rasa agar lebih ditingkatkan pelayanannya untuk dapat meningkatkan dan mempertahankan kepuasan konsumen dirumah makan panca rasa puruk cahu, memperbaiki sistem transaksi sehingga tidak ada konsumen mengeluh dalam melakukan traksasi karena adanya antrian.

2) Diusahakan karyawan selalu stand by agar pelanggan tidak perlu mencari dahulu saat ada keluhan.

3) Jam oprasional yan tidak menentu juga salah satu keluhan pelanggan karena tidak sedikit pelanggan rumah makan Panca Rasa yang bertempat tinggal jauh sehinnga menimbulkan kekecewaan pelanggan dan akhirnya pindah tempat makan.

4) Rumah makan panca rasa puruk cahu harus bisa bersaing dengan rumah makan lain yang sekarang sudah menjamur di puruk cahu.

Semoga dengan adanya masukan ini rumah makan bisa memperbaiki apa yang dikeluh kan pelanggan, sehingga bisa menjadi lebih baik dalam pelayanan dan bisa menjadi rumah makan yang paling di sukai pelanggan yang ada di Kab. Murung Raya

\section{Daftar Rujukan}

Afifuddin. 2009. Metodologi Penelitian Kualitatif. Bandung: CV. Pustaka Setia.

Dharmayasa, I Putu Arya., Lulup Endah Tripalupi. 2014. Analisis Kualitas Pelayanan Yang Diberikan Oleh Pegawai Administrasi Fakultas Ekonomi Dan Bisnis (Feb) Ditinjau Dari Kepmen Ppan No.63 Tahun 2003. Ekuitas-Jurnal Pendidikan Ekonomi, 2(1): 19-29 Https://Ejournal.Undiksha.Ac.Id/Index.Php/Eku/Article/View/12770

Gerson, R. 2004. Mengukur Kepuasan Pelanggan. Jakarta: PPM

Hariatama, Fendy. 2021. Analisis SWOT Terhadap Pelaksanaan Bauran Pemasaran (Marketing Mix) Pada Lembaga Pendidikan Prima Mandiri Utama Palangka Raya. Edunomics Journal, 2(1): 1-12. https://ejournal.upr.ac.id/index.php/edu/article/view/2078

Hasibuan, H Malayu S.P. 2008. Manajemen Sumber Daya Manusia Edisi Revisi. Jakarta: PT. Bumi Aksara

Kotler, Philip.2006. Manajemen Pemasaran. Edisi pertama. Indonesia: PT. Indeks Kelompok Gremedia.

Moleong, Lexy J. 2007. Metodologi Penelitian Kualitatif. Bandung: PT. Remaja Rordakarya.

Mursid, M. 2014. Manajemen Pemasaran. Jakarta: Bumi Aksara.

Nasution, M N. 2004. Manajemen Jasa Terpadu. Bojongkerta, Ciawi Bogor Sealatan: Ghalia Indonesia

Sartika, Yunisa., Tonich Uda, Rinto Alexandro. 2019. Pengaruh Kualitas Jasa Pelayanan Terhadap Kepuasan Konsumen Pada Toko Cahaya Di Kecamatan Laung Tuhup Kabupaten Murung Raya. Jurnal Pendidikan Ilmu Pengetahuan Sosial (JPIPS), 11(2): 296-301. https://ejournal.upr.ac.id/index.php/JP-IPS/article/view/514

Sugiyono .2007. Metode Penelitian Kuantitatif dan Kualitatif dan R\&D. Bandung CV Alfabeta

Widoyoko, Eko Putro. 2014. Teknik Instrumen Penelitian. Yogyakarta: Pustaka Pelajar

Wirapradnyana, Gede Adi. 2013. Faktor-Faktor Yang Mempengaruhi Keputusan Konsumen Menjadi Nasabah Bank Syariah. Ekuitas-Jurnal Pendidikan Ekonomi, 1(1): 96-105. Https://Ejournal.Undiksha.Ac.Id/Index.Php/Eku/Article/View/12765/8023 